\title{
Movement, Scope, and LF between Al-Jurjani and Chomsky
}

\author{
Nesrin Mohamed Imam Ibrahim \\ English Department, Faculty of Women, Ain Shams University \\ Nesrin.Mohamed@women.asu.edu.eg \\ Dr. Wafaa Abdel-Faheem Batran \\ Dr. Amira Ahmed Youssef \\ Professor of Linguistics, English \\ Professor of Linguistics \\ Department, Faculty of Women Ain \\ Shams University \\ Dr. Rania Galal Hamed \\ Arabic Department, Faculty of Women \\ Ain Shams University \\ Lecturer of Linguistics, Department of English \\ Faculty of Women, Ain Shams University
}

\begin{abstract}
The current research centers on the concepts of Movement, Scope, and Logical Form (LF) - as explored by al-Jurjani, specifically, the terms al-taPӨi:r and alhaiz which correspond to the terms of Scope and Domain respectively. The main objective is to investigate the semantic Scope and syntactic C-Command relation of the logical operators in Classical Arabic (CA). It has been argued that the universal quantifier kul "all" has a narrow scope reading conveying the existential meaning 'some' when it is c-commanded by the past-tense negative operator lam. However, when it undergoes syntactic movement to the left periphery where it c-commands the negative operator, it takes a wide scope over the negative operator, and thus has universal reading. Therefore, Scope in CA is determined at surface structure, not at the LF level.
\end{abstract}

Keywords: Scope, C-Command, Movement, Logical Form, Classical Arabic, logical operators

\section{Introduction:}

This paper proposes that, in CA, when the universal quantifier $k u l$ "all" is within the scope of the negative operator, the negative operator has wide scope and $k u l$ has narrow scope. However, when the universal quantifier moves to the front of the structure outside the scope of the negative operator, it has wide scope and an entirely different reading is obtained. The two readings can be predicted adopting the concepts of C-Ccommand, Scope and LF within Chomsky's Minimalist framework (1993 and 1995). Throughout the paper, it is demonstrated that al-Jurjani's treatment of the concepts of Movement, Scope, 
and Logical Structure of language highlights the relation between syntax and semantics.

The narrow scope and wide scope interaction changes the meaning. This change in meaning can be illustrated in the following two examples from alJurjani (2001, p.186):

1) lam ja?t kul-u al qawm-i

Not-past come-juss all-nom the-people-gen

"All the people did not come"

2) kul-u al qawm-i lam ja?t-u:

All the -people not-past come-plural

"All the people did not come"

In example 1, the negative particle lam outscopes the universal quantifier $k u l$ "all". This yields the meaning of the sentence as "some of the people came". In example 2, fronting the quantifier results in it having wide scope over the negative operator which gives the meaning of "none of the people came". How can we account for this difference in meaning? By investigating the notions of logical structure, scope, and c-command in the above examples, a straightforward account for the two readings caused by the scope interaction can be provided.

Central to this paper's analysis is the Split Complementizer Phrase (CP) Hypothesis proposed by Rizzi (1997). The main idea in this proposal is that CP is split into three distinct layers, namely, Force Phrase (ForceP), Topic Phrase (TopP), and Focus Phrase (FocP). The motivation behind this suggestion is pragmatic in nature where new information is positioned in Specifier (Spec) FocP position while older information already mentioned in the discourse is moved into Spec TopP. Meanwhile, Spec ForceP hosts the force of the clause in accordance with the Clause-Typing Condition (Cheng 1997). This condition specifies the force of the clause to be declarative, exclamative, or interrogative.

Split-CP analysis is utilized in this paper to demonstrate the position where the topicalized Quantifier Phrase (QP) moves in CA, which is suggested to be Spec TopP since it does not convey contrastive information. The following examples adapted from Rizzi (1997, p.286) clarify the difference between topicalized and focused elements: 
3) Your book, I have read it. (Topicalized DP "your book")

4) Your book I read, (not his). (Focused DP "your book")

In these two examples, the topicalized DP in 3 moves to Spec TopP, while the focalized DP in 4 moves to Spec FocP. Adopting Rizzi's hypothesis, Gad (2011) argues that the fronting of wh-phrases in Egyptian Arabic is mainly triggered by Focus purposes. To illustrate Gad's proposal, in the example: mi:n illi fatat il ba:b? (who that opened the door) "Who opened the door?" (Gad, 2011, p.218, no.154), the relative pronoun illi "that" occupies the head Foc position of the FocP.

Moreover, the vP Shell Hypothesis advanced by Larson (1988) is used in the analysis of the current paper to account for the inner structure of the VPs. The central assumption in this hypothesis is that VP is split into two layers. These two layers are the inner core VP and the outer vP shell which has the agent subject in its Spec position.

Investigation of meaning in this paper is conducted within Chomsky's framework. Chomsky $(1955,1965,1981,1995)$ in his Generative Grammar enterprise attempted to research how syntactic structure derives meaning. In his Standard Theory, Chomsky $(1957,1965)$ argued that meaning is found in the $\mathrm{D}$ (eep)-Structure where thematic roles are assigned. However, within the Minimalist Program (MP), Chomsky (1995) proposed that meaning is to be found in the LF level of representation. This level accounts for the meaning of quantification and negation.

\section{Purpose and Organization of the Paper:}

Al-Jurjani, the medieval CA grammarian in his seminal work dala:Pil-u al-iSdza:z-i Signs of Inimitability" -written in the $11^{\text {th }}$ century- presented the

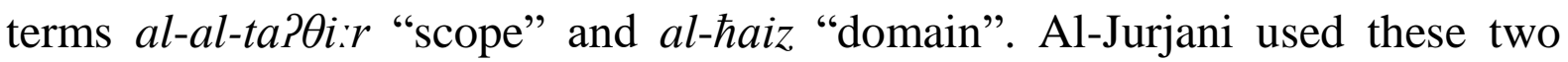
terms to explain the linguistic phenomenon of the semantic scope interaction exercised by the negative particles lam and ma:, and the quantifier kul "all". The analysis of his data is conducted using the concepts of Chomsky's Generative Grammar, namely, Movement, Scope, and the LF. The scope of negative and quantifier logical operators is examined in the light of these Chomskyan notions.

The present paper is divided into 6 sections. Section 1 is introduction. Section 2 is Purpose and Organization of the paper. Section 3 is an overview of Chomsky's LF, Movement and Scope. Section 4 is an overview of al-Jurjani's 
book. Section 5 is Logical Operators and Domain of negative and universal operators. This section includes the proposed analysis of the Scope and Logical Structure of the data. Finally, Section 6 is Conclusion.

\section{Chomaky's LF, Movement, and Scope:}

LF is a level of representation that encodes the semantic properties of natural language sentences. This level corresponds to the D-Structure in the Government and Binding theory (GB) (Chomsky, 1981) where the D-Structure and (S)urface-Structure are the levels of representation of sentences. Chomsky's Minimalism (1995) differs from GB in the absence of these two levels. Instead, the MP assumes only two levels, namely, Phonetic Form (PF) and LF. Grammatical well-formedness is determined in these two levels. Aspects of meaning such as relative quantifier scope, pronoun binding, variable binding, focus and presupposition, and scope of negation- are determined at LF (Hornstein, 1995). This research paper is concerned with quantifier scope and negation scope.

\subsection{The Scope of Logical Operators:}

The concept of scope has been discussed early in the introduction of LF. When the semantic interpretation of some expression is affected by an operator, thus the operator has scope over that expression. Quantifiers are scopal elements. They have scope by the rule of Move $\alpha$ at LF. The QP moves to adjoin the quantified Noun Phrases (NPs). The QPs exercise scope over their NP complements. Scope is closely related to the c-command relationship (Huang, 1994).

According to Dayal (2012), mainstream treatment of quantification involves investigating the logic of predicates and logical calculus. In the following examples, it is demonstrated that a quantifier has scope over the structure containing it:

5) a. $\forall x[\operatorname{student}(x) \rightarrow \operatorname{study}(x)]$

b. $\forall \mathrm{x} \exists \mathrm{y}$ like (x, y)

c. $\exists$ y $\forall \mathrm{x}$ like $(\mathrm{x}, \mathrm{y})$

In these examples, in 5a the universal quantifier $\forall$ has scope over [student $(x) \rightarrow \operatorname{study}(x)]$. The relation of wide or narrow scope is identified when a quantified formula contains a quantifier. $\forall$ has wide scope over $\exists$ in 5 b. However, in $5 \mathrm{c}$, it is the existential quantifier $\exists$ that has scope on $\forall$. 
Other scopal elements can enter into interactions with quantifiers such as negation operators. This is allowed within the studies on the syntax of predicate logic. (Dayal, 2012)

In order to support the LF existence, May (1985) argued for a Quantifier Raising $(\mathrm{QR})$ operation to account for the following example:

6) John saw everyone.

This is parallel to the wh-movement as in the following example:

7) Who did John see?

The QR application results in the following scheme:

[s' who [s did John see $\left.{ }_{\mathrm{t} 2}\right]$ ]

[s everyone [s John saw t2]] (May's examples cited in Jenks (2013), p.1)

The study of scope within the GB theory (Chomsky 1981) witnessed an important stage when May (1977 and 1985) proposed the principles that govern scope:

Scope Principle:

Quantifiers symmetrically c-commanding each other can have scope in either order.

The Condition on Quantifier Binding:

Every quantified phrase must properly bind a variable

Condition on Proper Binding:

Every variable occupying an argument position must be properly bound

\section{C-Command Condition:}

$\alpha$ c.commands $\beta$ iff every maximal projection dominating $\alpha$ dominates $\beta$ and $\alpha$ does not dominate $\beta$

Reinhart (1976) suggests that scope and c-command relation are inseparable at the surface structure. Based on this assumption, the following example, in Reinhart's view, has only one reading:

8) Every man loves some woman (Ruys, 2002, p.2, no. (4)) 
This sentence is true only if for every man, there is a woman that he loves. In contrast, according to the inverse scope reading proposed by May in 1977, two readings are available for the above example. Thus it could also mean there is a woman such that every man loves her. Quantified NPs give rise to the phenomenon of wide versus narrow scope binding as demonstrated in the above example in 8.

According to Huang (1994), the LF level of representation serves to mediate between the syntactic form of a structure as far as trees are concerned and its semantic aspect in terms of its truth conditions and entailments. Truth conditions can be captured using logical structure. Huang (1994, p.128, no.(2, 3 and 4)) provides the following example:

9) Every student flunked

The following logical formulae are used to illustrate the truth conditions of the above example.

$$
\begin{aligned}
& \forall \mathrm{x}((\mathrm{x} \text { is a student }) \rightarrow(\mathrm{x} \text { flunked })) \\
& (\forall \mathrm{x}: \mathrm{x} \text { is a student })(\mathrm{x} \text { flunked })
\end{aligned}
$$

The subject student is a variable bound by the universal quantifier every.

The interaction of wide and narrow scope is a manifestation of the syntax-semantics interface. (Bernardi, 2002, p.95, no (1)). For example:

11) John wants to marry a Canadian princess.

12) Every boy read two books.

In these examples, scope ambiguities are exhibited by the quantified NPs having either narrow or wide scope. In 11, a Canadian princess is a quantified indefinite which is presupposed to exist. When this quantified NP has narrow scope i.e. falling under the scope of want, the speaker does not presuppose the existence of a specific Canadian princess $(\neg \exists)$. However, when the QP has wide scope over the verb want, the speaker presupposes the existence of such a person $(\exists \neg)$.

In 12, if the indefinite QP two books exercises scope over every boy, then the sentence will yield the interpretation of "There are two specific books that every boy read'. On the other hand, if the universally quantified NP every boy outscopes the QP two books, then there will be two books read by every student and so the number of books is much larger than two (ibid). 


\subsection{The Theory of Movement:}

Chomsky's (1981) theory of Movement is a principal property of his proposed enterprise Universal Grammar. Two major types of movement are found in English, namely, A-movement and A-bar movement. The former refers to the movement of subjects from their original position within the Verb Phrase (VP) into Spec T position. The latter type of movement indicates the movement of a wh-operator to a position outside the TP, namely, Spec C. Movement theory is encompassed in the more general notion of Move alpha (Chomsky, 1980) which means move any category anywhere.

Chomsky (1977) explains that when a wh-phrase moves, it leaves a trace behind. He states (p.82): "wh-movement leaves a non-terminal trace. That is the position from which the wh-phrase moved remains in the derived constituent structure with its index, identical to the index of the wh-phrase, now in COMP".

Within the Extended Standard Theory, Chomsky (1980 p.3) argues that movement rules are "restrictive to the single rule Move a, where a is a category". In 1981, he explains that the trace left behind is a variable co-indexed with the wh operator that binds it. This conforms to the binding relation defined as follows: A binds B iff A c-commands B where A and B are co-indexed.

Chomsky (1986) introduces the functional categories Complementizer and Inflection into the X-bar theory of maximal projections. He assumes the Spec of CP to be the position to which the wh-phrase moves, and the Spec of IP to be the location of the subject NP.

With the introduction of the MP, the economy principle emerges (Chomsky,1995). This principle aims to minimize the derivation and to reduce the number of conditions and constraints imposed on the grammar. As a result, movement operations are driven by morphological necessity. This means that features must be checked, otherwise, the derivation crashes. These features are the abstract question affix Q on the head $\mathrm{C}$ at the LF level.

Within the Minimalist framework (Chomsky, 1993 and 1995), movements are generally triggered by features. What instigates the subject movement is the Extended Projection Principle (EPP) on T which requires it to have a subject (Chomsky, 1982, 1995). By the same token, the wh-operator movement in English is triggered by the Edge Feature (EF) on the head. For example:

13) John will see Bill. (Koopman and Sportiche, 1991, p.211, no.(1a)) 
14) Who does Bill like? (Horvath, 2005, p.4, no. (4))

Chomsky (1977) argues that whenever an element moves, it leaves a trace behind which eventually gets deleted. Furthermore, Chomsky (1981) suggests that this trace is a variable that is co-indexed with the wh-word that binds it. Therefore, the structure of each of the above examples 13 and 14 is respectively as follows where wh-op stands for wh-operator:

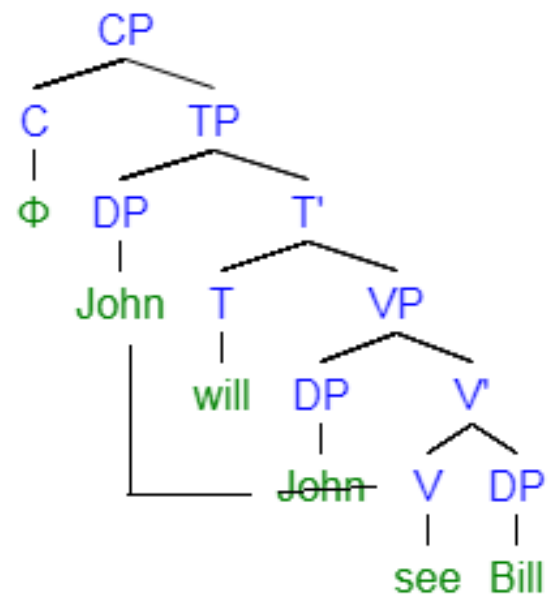

(14a)

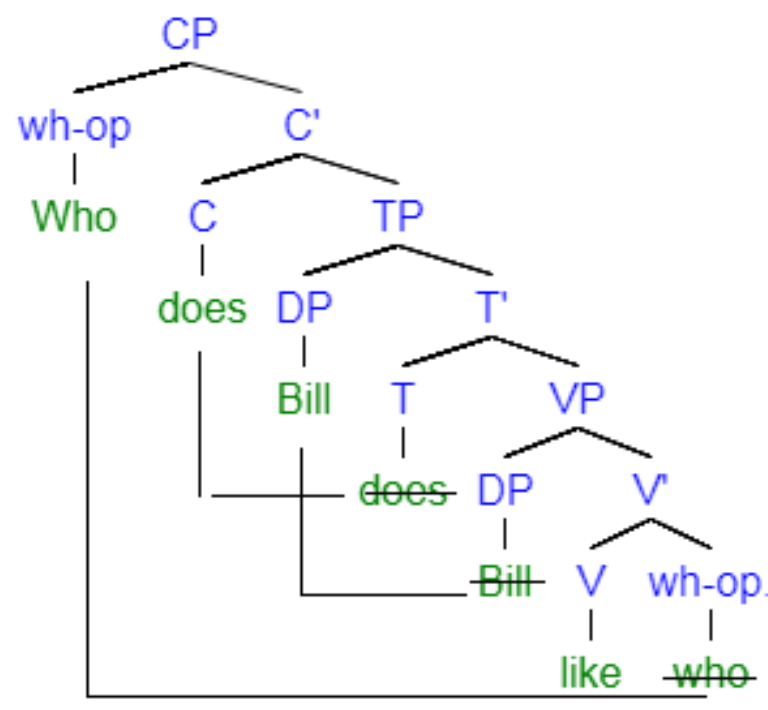

In these two tree diagrams, the moved element leaves a trace behind that gets deleted after the movement occurs. The deletion step is expressed by a strikethrough on the deleted element. It is note-worthy that in $14 \mathrm{a}$, the wh- 
operator moves to a clause-initial position where it c-commands the entire structure as per Chomsky and Lasnik (1977). Moreover, Wahba's (1991) analysis of Iraqi Arabic data suggests that the wh-operator must have wide scope over the whole sentence regardless of the position it occupies; whether it occurs in-situ, in the matrix Comp, or even the intermediate Comp.

Having briefly reviewed the concepts of Movement, Scope and LF in the literature, the next section gives an overview of al-Jurjani's book from which the research draws its CA data.

\section{Al-Jurjani's Book:}

This paper draws on data presented in al-Jurjani's treatise on CA grammar and meaning dala:Pil-u al-iSdza:z-i "Signs of Inimitability" (2001) written in the eleventh century. In this book, al-Jurjani proposes his theory alnazm "syntactic theory", dealing with important linguistic phenomena in CA grammar and relates it to meaning. Interestingly, al-Jurjani's ideas are - to a certain extent - the nucleus of Chomsky's Generative Grammar enterprise. AlJurjani discussed linguistic issues that are the center of attention in modern linguistics. For instance, he examined the concepts of movement, scope and the logical structure of language, thus highlighting the relation between syntax and semantics.

\section{Logical Operators and Domain: Negative Operator and Universal Operator:}

This section demonstrates how al-Jurjani dealt with the scopal interaction of logical operators; namely, the negative and the quantifier operators. He dealt with the concepts of movement, scope, and logical operators and his examples are also explained in set theoretic symbols as a tool to reveal the sentences' logical interpretation.

Al-Jurjani (2001, p.183) argues: "(using) "kul" "all" while the verb is negated gives the meaning (of partial existence) that there were some and some others were not". He gives the following examples:

15) a. lam Palq kul-a al-qawm-i

Not-past meet all-acc the-people-gen

"I did not meet all the people"

b. lam Pa:xuð kul-a al-darahim-i 
Not-past take all-acc the-dirhams-gen

"I did not take all the dirhams"

In traditional CA grammar (al-Zajjaji, 1984), the negative particle lam assigns jussive case to its complement verb. In these two examples in 15, alJurjani (2001, p184) assumes a semantic ambiguity. He disambiguates the meaning arguing that:

"The meaning (given) is that you met some of the people and not all of them, and that you took some of the dirhams and left the rest. The sentences do not mean that you did not meet any one of the people nor do they mean that you did not take any of the dirhams".

Thus, the quantifier kul "all" in each of the two examples has a sense of partiality, i.e. the existential meaning. $(\neg \forall)$.

Concerning the negative particle lam, negation is a special trait that makes CA quite discernible from other languages. CA is distinguished in terms of its tensed negative particles. According to Benmamoun (2000), Shlonsky (1997), and Ouhalla \& Shlonsky (2002), the negative particles in Standard Arabic (SA) which is similar to CA are la: lam, lan, ma:, and laisa. Each one has different syntactic features, with lam and lan carrying tense. The negative particle "lam" has past tense, lan future tense, and la: carries present tense negation. They occur with imperfective verbs, and lam occurs with non-finite verbs.

Based on the assumption that CA has verb movement- as suggested by Benmamoun (2000), Mohammad (2000), Fakih (2006) to name but a fewwhich proposes that the verb moves from $\mathrm{V}$ to $\mathrm{T}$ to check its Agr features and satisfy the EPP requirement on $\mathrm{T}$, tense originates under the head $\mathrm{T}$, but where should the Negation Phrase (NegP) be located? Should it be under the TP or above it? Two competing analyses could be found (called Low-Neg and HighNeg analyses by Soltan, 2011). These two propositions are: Benmamoun (1992 and 2000), and Ouhalla (1993) on the one hand, and Soltan's suggestion in 2007 on the other hand. As for the former analysis, Benmamoun and Ouhalla assume the place of NegP to be between TP and VP, whereas the latter analysis locates it above TP. The following schemes illustrate the two proposals (Soltan, 2017, p.119, no.7):

High-Neg: 


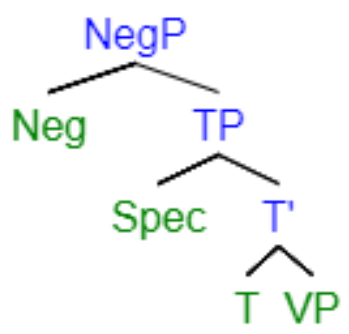

Low-Neg:

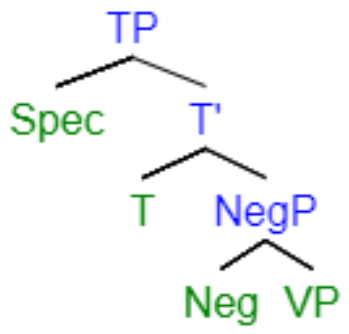

Sentential negation in SA is assumed by Benmamoun (1992 and 2000) and Ouhalla (1993) to be functional projection headed by the negative particle. They further argued that negative particles in SA are located between TP and VP. Therefore, negative elements in SA occupy the head of NegP that is under the TP. This results in the negative head being the host of tense not the verb. The following structure illustrates this proposal where the negative particle is the head Neg and it negates the NP muћammad-un ka:tib-un "muћammad is a writer" with both nouns carrying the nominative case.

(16a)

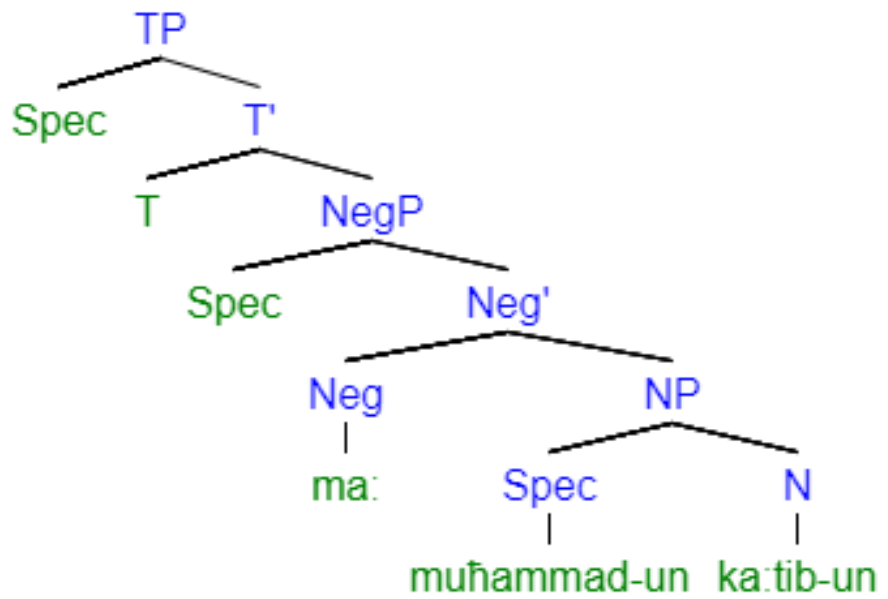

(Benmamoun, 2000, p.108) 
Nevertheless, this analysis is not without problems. It leads to the problem of the verb occupying a position higher than the negative element to check its Tense and phi-features. In order to avoid this problem, Soltan (2007) proposes alternative analysis which he bases on the feature-checking theory presented within the framework of the MP (Chomsky 1993 and 1995). He suggests that the negative head is positioned higher than TP and has the feature $\{+$ Tense $\}$. This tense feature on negation drives it to undergo checking relation with the tense feature on the verb resulting in tense being spelled out on the negative head located in a position higher than the verb. This proposal can be illustrated below:

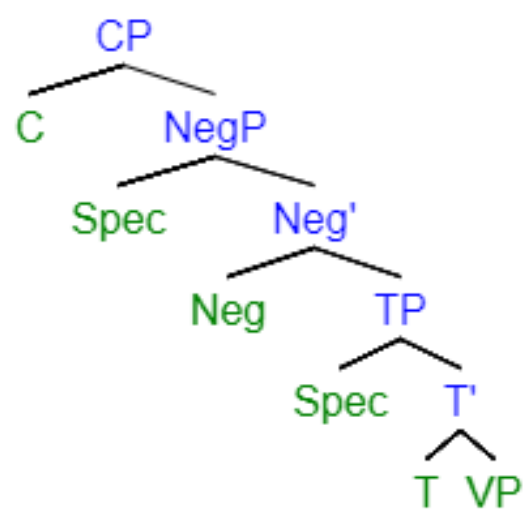

Of these two analyses, this paper refutes the so-called Low-Neg analysis, and advocates the High-Neg analysis assuming that the NegP is located under the $\mathrm{CP}$, not under the TP. This is because the verb in T lacks the tense feature and thus has the feature $\{$-Tense $\}$. This is evidenced by the ungrammaticality of the following sentence:

16) *lam dza:?a kul-u al-qawm-i

Not-past came all-nom the-people-gen

"All the people did not come"

In this example, the tensed verb renders the structure ungrammatical because the negative particle lam has the tense already spelled on it, and it is past. Thus, the tense is carried by the negative particle and the verb should be non-finite. Therefore, this paper argues that $\mathrm{NegP}$ is positioned under the $\mathrm{CP}$.

In traditional Arabic grammar, the quantifier kul is morphologicallymarked for case. When it modifies a plural definite noun, this quantifier 
signifies universal meaning "all", whereas when modifying a singular indefinite noun, it denotes the meaning of "each". For example:

17)

a. kul-u al-na:s-i dza:?-u:

"All-nom the-people-gen came-plural".

"All the people came".

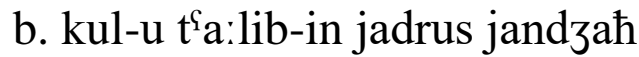

Each-nom student-gen studies succeeds

"Each student that studies will succeed". (adapted from Amer, 2003, p.8, no.17).

In traditional Arabic grammar, the quantifier kul -together with its modified noun- forms "id $a f a$ " construction "a construct state" which assigns genitive case to the modified noun (Sibaweih, 1977).

The concern of the current paper is mainly the quantifier kul with the universal meaning "all". According to Abney (1987), this universal quantifier is considered a Spec of the DP it modifies. Sportiche (1988) maintains that it is adjoined to the DP. On the other hand, Shlonsky (1991), suggests that kul in Hebrew is a functional head.

Following Shlonsky, Amer (2003) argues that kul forms a functional head in Standard Arabic (SA). He bases this assumption on the ability of kul to host a clitic. He provides the following examples (p.9, no.23):

18)

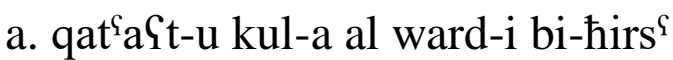

I-cut-past all-acc the-flowers-gen with-care

"I cut all the-flowers carefully".

b. qat ${ }^{\uparrow} a 9 t-u$ al-ward-a kul-a-hu bi-hirs ${ }^{\varsigma}$

I-cut-past the-flowers all-of it with-care

"I cut all the flowers carefully".

According to him, both examples are synonymous. In $18 \mathrm{~b}$, when the quantifier follows al-ward- $a$, it hosts a clitic pronoun which in turn is coindexed with the quantified DP. This quantifier with a clitic attached to it also agrees with the preceding DP in number, gender, and case. Thus, hosting a clitic 
forms an evidence for Amer (2003) to assume that quantifier is a functional head in SA. This argument is based on Shlonsky's (1991) proposal that only functional heads are able to host clitics. As a result, Amer concludes that the Arabic quantifier is a head of the NP it modifies and behaves like a nominal head whereby it receives case, modify definite (or indefinite) nouns, and can be a head of genitive constructions.

Amer (2003, p.11, no.27) supports his view that quantifiers are heads of the DPs they modify by providing the following example and tree:

19) kul-u ha?ula:? al-Pawla:d-i mahara

All-nom these the-boys-gen clever

"All these boys are clever".

The tree diagram that represents the analysis of this sentence is as follows:

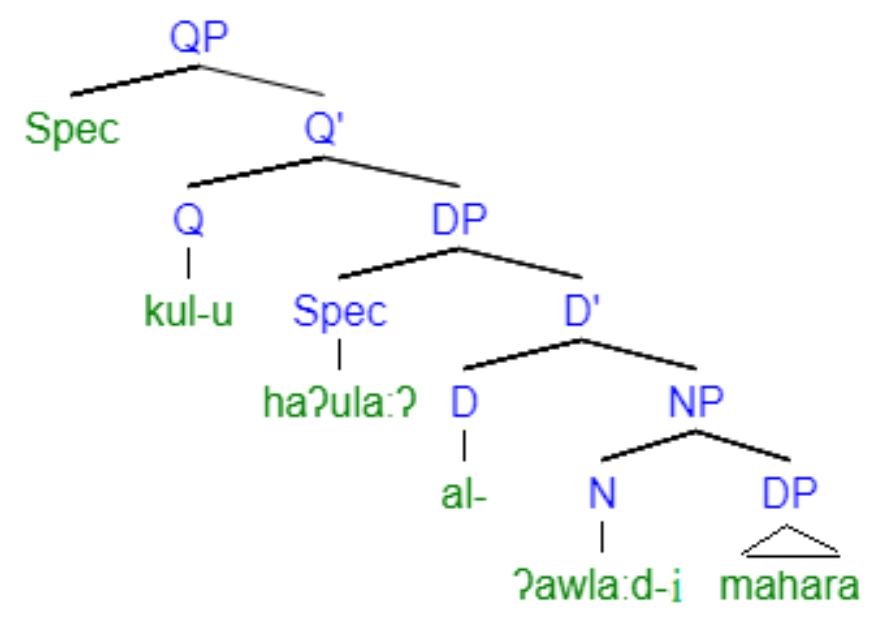

Benmamoun (1999) maintains that the quantifier appears in two models. These two models are: Q- NP and NP- $-\mathrm{Q}$ interchangeably. The two patterns are illustrated in the following examples (adapted from al-Jurjani, 2001):

20)

a. dza:?a kul-u al-qawm-i

Came all-nom the-people-gen

"All the people came".

b. dza:Pa al-qawm-u kul-u-hum 
Came the-people-nom all-of them

"All the people came".

Nevertheless, Benmamoun refutes Shlonsky's (1991) assumption that the quantifier $k u l$ heads a QP projection having NP as a complement in both patterns. Alternatively, Benmamoun argues that the two patterns are essentially different. In the Q--NP pattern, the quantifier is the head of a QP projection. However, in the NP-Q model, the quantifier heads a QP adjunct modifying the NP.

Analyzing the sentences in 1 and 2, lam ja?t kul-u al-qawm-i "all the people did not come" and kul-u al-qawm-i lam ja?t-u: "all the people did not come", their hierarchical structure will be as follows- adopting the Split CP analysis proposed by Rizzi (1997) to account for the topicalized QP:

Thus, returning to example 1, it is structured as below:

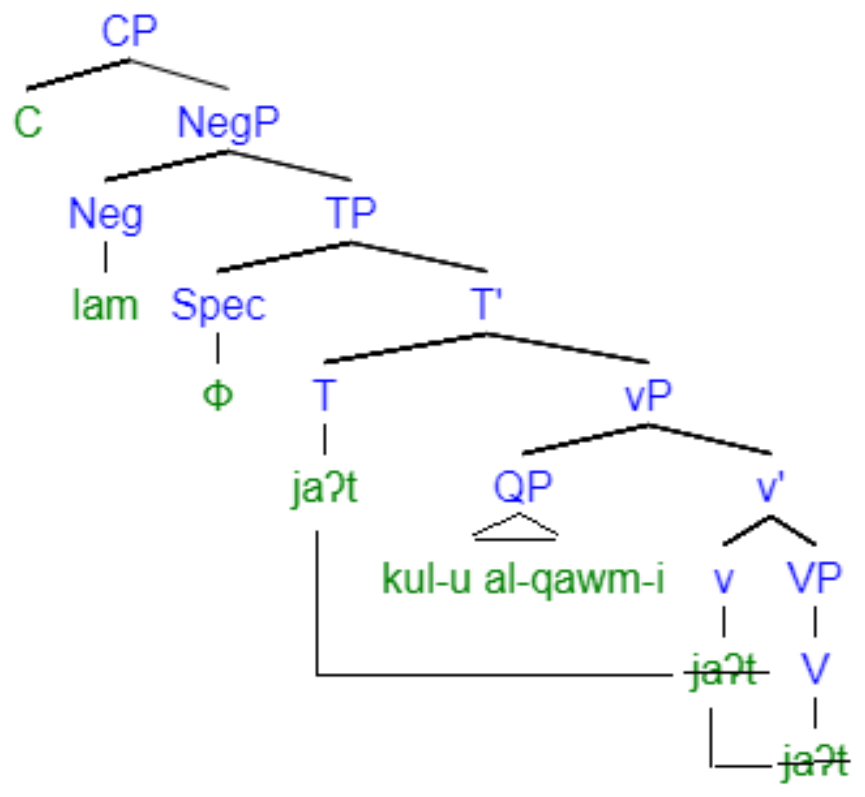

Here the subject stays in-situ to result in the S-structure Verb-Subject-Object (VSO) word order.

As for sentence 2, it is structured as follows: 


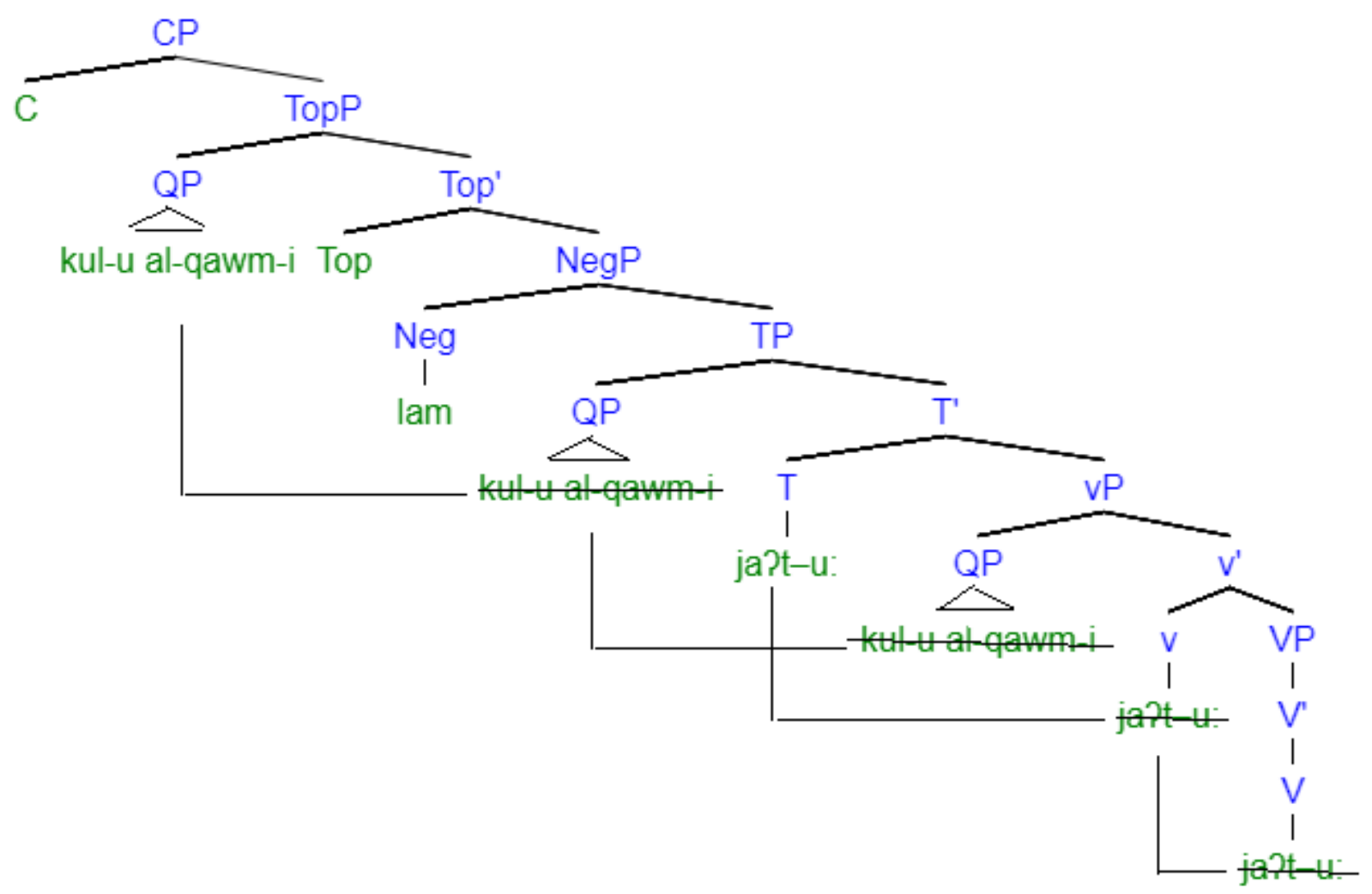

Here the subject is topicalized in the sense of Rizzi (1997) and the subject undergoes cyclic A-movement in accordance with the Head Movement Constraint (HMC) whereby Travis (1984) postulates that the movement occurs between the head and the next highest head in the tree. This cyclic movement takes place where the subject QP kul-u al-qawm-i moves from the Spec of vP to Spec of TP and finally lands in Spec TopP.

The negative operator in 1 is followed by Verb-Subject (VS) word order whereby the verb has partial agreement with the subject. Whereas in example 2, the QP is fronted resulting in Subject-Verb (SV) word order and the agreement pattern changes. In 2 the verb exhibits full agreement with the preverbal subject by ending with the third person plural masculine suffix $-\mathrm{u}$ : . To account for this, Benmamoun (1992) argues that partial agreement in VS stems from the government configurations where the verb in the head $\mathrm{T}$ governs the subject. As for the SV full agreement, it is due to the Spec-Head relation that is established between the subject in the Spec T position and the head V.

Al-Jurjani uses affirmative sentences as a semantic evidence to support his view that the quantifier kul "all" falls within the negation domain. Just as negation directly affects the quantification in the negative sentences, affirmation also directly affects the quantification meaning in affirmative sentences. Al- 
Jurjani illustrates that the use of the quantifier kul can be to emphasise the meaning of inclusiveness or totality of the subject that performed the action expressed by the verb in both affirmation and negation. He provides the following affirmative examples:

21) dza:?a-ni al-qawm-u kul-u-hum

Came-to me the-people-nom all-nom-of them

"All the people came to me"

22) dza:Pa-ni al-qawm-u

Came-to me the-people-nom

"The people came to me"

In 21, kul-u-hum "all of them" is considered tawki:d "emphasis" in traditional CA grammar (Al-Zajjaji, 1984). It emphasises the sense of inclusiveness of the noun it modifies, i.e. the totality of the people came.

As for the example in 22, al-Jurjani argues:

"If you just said dza:?a-ni al-qawm-u "the people came to me", the hearer would think that some (of the people) came and some others are left behind but that you overlooked their absence, or that you made the action of coming occur by some of the people as if it were by all of them".

So it is not clear whether some people or all people came. Thus this example in 22 has a sense of semantic ambiguity. Such an ambiguity stems from the two interpretations for the sentence as al-Jurjani explained. One is that some of the people may not have done the action of coming, the other interpretation is that only some of them came but it was considered as if all of them did come in what is called metonymy. This term is explained by Lakoff and Johnson (1980) to be a relation of proximity between the part and the whole.

The sense of tawki:d "emphasis" is considered by al-Jurjani to be a kind of semantic restriction or what he calls "al-qaid" which is found in the above sentence where $k u l$ "all" is used to confine the meaning of the verb to a sense of inclusiveness. In other words, it has a semantic effect of emphasis on the inclusiveness meaning on the noun it modifies. 
Al-Jurjani (2001) postulates a generalization which states that when negation is added to a sentence, and that sentence contains a (semantic) restriction of some kind such as tawki:d "emphasis" or depictive noun - in this case the tawki:d "emphasis" - the negation is exclusively directed at that restriction. He states (2001, p.183):

"Here is the rule of negation when it is added to a sentence with a (semantic)

restriction, and emphasis is a type of restriction: If you negate a sentence that contains tawki:d emphasis, this negation is directed to that emphasis exclusively and occurs to it".

In 21, the QP kul-u-hum is part of adjunct CP sister to the V-bar level of the VP dza:?a-ni al qawm-u. The subject occurs in the position of Spec VP in accordance with VP-Internal Subject Hypothesis proposed by Kuroda (1988) and Koopman \& Sportiche (1988) among others.

The depictive clause is another semantic restriction to which the scope of negation is directed. Consider the following examples:

23) Pata:-ni al-qawm-u mudztams-i:n

Came-to me the-people-nom gathered-plural

"The people came to me gathered"

24) lam ja?t-ni al-qawm-u mudztams-i:n

Not-past came-to me the-people-nom gathered-plural

"The people did not come to me gathered"

Al-Jurjani provides the following explanation for his sentences (in 23 and 24):

"The negation in these sentences is directed to the "gathering" which is (considered) a (semantic) restriction on (the action of) coming itself. If we wanted to negate the (action of) coming itself, we could have said lam ja?t-u:ka as ${ }^{\complement l-a n}$ "They did not come at all"”. (al-Jurjani, 2001, p.183184).

The noun mudztam -i:n "gathered" is a depictive noun in traditional CA grammar (al-Zajaji, 1984). It is considered a secondary predicate by al-Jurjani (2001). Khalil (2012) pointed out to the resemblance between the secondary predicate, or the depictive clause in CA and the Small Clause phenomenon in 
English (the term first appeared in Williams, 1975) but this is beyond the scope of the current paper. Example 24 can be analysed in the following hierarchical structure:

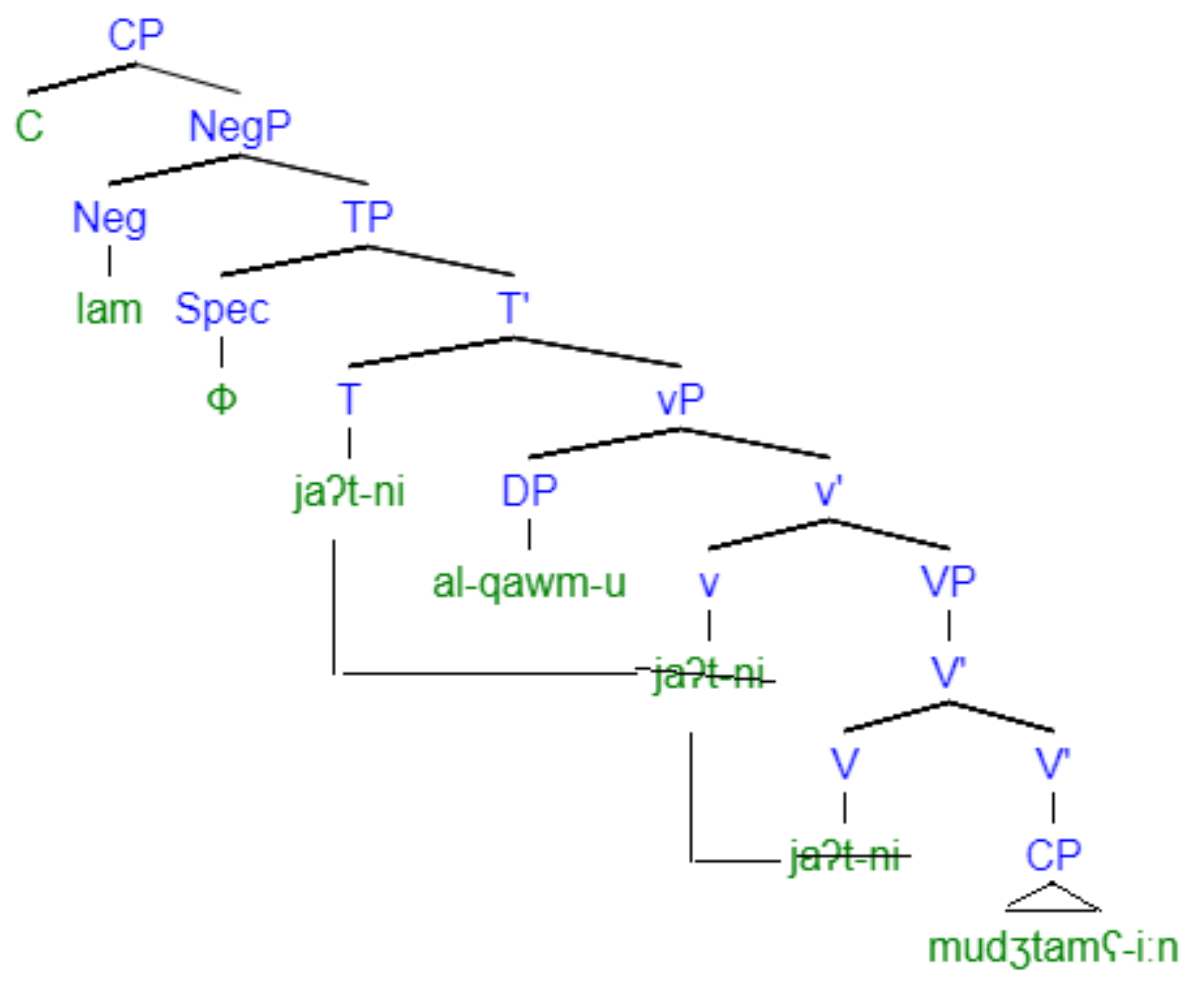

So, the depictive noun mudztams-i:n "gathered" is what is being negated by the negative particle lam. In terms of the logical structure analysis, the semantic scope of lam is on the adjunct mudztam $-i: n$ "gathered" and not on the action of coming per se. The meaning is "Not gathered is such that people came".

Assuming that $\mathrm{NegP}$ is located above the TP, the negative operator is the head of its functional projection. The verb moves from $\mathrm{V}$ to $\mathrm{T}$ which lacks tense because the tense is already spelled out on the head Neg. The subject al-qawm-u originates in the Spec-VP and remains in situ to achieve the VS order.

Al-Jurjani provides more examples to illustrate his point:

25) lam Par al-qawm-a kul-a-hum

Not-past see the-people-acc all-of them

"I did not see all the people" 
26) lam Par kul-a al-qawm-i

Not-past see all-acc the-people-gen

"I did not see all the people"

27) lam ja?t-ni al-qawm-u kul-u-hum

Not-past come-to me the people-nom all-of them

"Not all the people came to me"

28) lam ja?t-ni kul-u al-qawm-i

not-past come-to me all-nom the-people-gen

"Not all the people came to me".

In 25 and 27, kul-u-hum "all of them" is tawki:d "emphasis" in CA traditional grammar (Al-Zajjaji, 1984). In 26 and 28, the quantifier $k u l$ is moved to form id $\mathrm{a}$ :fa "construct state" structure along with its modified noun alqawm-i which has the genitive case.

Al-Jurjani (2001, p.184) explains that in the above sentences "you directed your negation to the meaning of $k u l$ "all" specifically, and it is the same as mudztam -i:n "gathered" in lam ja?t-ni al-qawm-u mudztam $S-i: n$ "the people did not come to me gathered"." Since negation only affects the quantifier kul "all", then it must be the case that "only some of them came".

Therefore, in terms of scope, the logical operator lam has the upper hand over the quantifier kul "all" and the latter has partial reading. In other words, the universal quantifier falls within the scope of the negative operator lam $(\neg \forall)$. The logical structure of the above examples in 25 and 26: "Not all of the people are such that I saw", and in 27 and 28 "Not all of the people such that they came".

Not only did al-Jurjani discuss the scope of the quantifier kul "all" in negative sentences, but also in the affirmative. For example:

29) dza:Pa-ni al-qawm-u kul-u-hum

came-to me the-people-nom all-nom-of them

"All the people came to me" 
In this example, the statement gives the meaning of the inclusive kul "all". According to al-Jurjani (2001, p.184):

"What matters in this sentence and that which you affirm is that there is no doubt in the inclusiveness of the act of coming. The doubt is not in the act of coming itself, but in the inclusive coming of "all" the people".

In this way, the semantic interpretation here is mainly to state the inclusiveness meaning.

Al-Jurjani concludes with another generalization which is "when an element is added to the affirmative statement, it is the gist meaning of that sentence to deliver". He provides the following example:

30) dza:Pa-ni zajd-un ra:kib-an

Came-to me zajd-nom riding-acc

"zayd came to me, riding"

31) ma: dza:Pa-ni zajd-un ra:kib-an

Not came-to me zajd-nom riding-acc

"zayd did not come to me riding"

He explains that these sentences contain an extra element which is ra:kiban "riding". This element is called secondary predicate by al-Jurjani. The scope of the meaning of either affirmation or negation falls on this added element. This affirmative meaning is what has semantic scope over ra:kib-an. This affirmative meaning stands in contrast with the negative particle $m a$ : which has scope on ra:kib-an in the negative sentence.

Al-Jurjani (2001, p.186) introduces the term al-ta? $\theta i: r$ "literally; effect" which corresponds to the term "scope", and the term al-haiz which corresponds to the term "domain". He states that "al-taPAi:r "scope" is not a result of the verb's ability to assign case, but it is (a result of) kul "all" whether enters the haiz "domain" of negation or not". He further elaborates: "The difference in meaning in the two above sentences is not due to the case assignment property of the negative particle ma: "not". But it is due to the effect of the negative particle on kul "all" and the possibility of entering kul "all" in the domain of the negative particle ma: "not". In other words, it is the semantic scope of negative ma: that falls on the quantifier kul. 
If the negative particle $m a$ : is not immediately adjacent to the verb as in the examples below (al-Jurjani, 2001, p.186), the scope of the negative particle will still have an effect on $k u l$ "all" $(\neg \forall)$.

$$
\text { ma: kul-u ma: jatamana: al-mar?-u judrik-uh }
$$

Not all-nom that wish the-man-nom realize-resumptive pronoun

"Man does not realize all that he wishes for"

$$
\text { ma: kul-u ra?i al-fata: jadৎ-u: ila: rufd-in }
$$

Not all-nom opinion the-boy guides to wisdom-gen

"The opinions of the boy are not wholly wise"

In 32, kul-u ma: jatamana: al-mar?-u is the complement of the negative particle and the original object of the verb judrik-uh. After kul-u ma jatamana: al-mar?- $u$ is fronted to become a nominative topic, it is replaced by the suffix resumptive pronoun attached to the verb. The topic is assigned nominative case in traditional Arabic grammar by being the mubdata? "topic" occupying the initial position. In 33, kul-u ra?i al-fata: is the clausal subject of jads-u: and is fronted to become a nominative topic.

The embedded clause QP kul-u ma: jatamana: al-mar?-u originates as the internal complement of the matrix verb judrik in the VP, and then gets raised to the A-position which is Spec TopP. The object clitic - $u$ h attached to the verb judrik is assumed to refer to the topicalized QP kul-u ma: jatamana: al-mar?-u. This assumption is based on the analysis of Jelinek (2002). Such an analysis suggests that after an NP is focused in Egyptian Arabic, a resumptive pronoun appears in its position.

The negative operator ma: has scope over $k u l$ and gives partial reading of it, $(\neg \forall)$. The meaning in 32 is "Not all what man wishes for is such that man realizes", and in 33 "Not all of the boy's opinions are such that they are wise". The structure of this sentence in 32 can be illustrated below: 


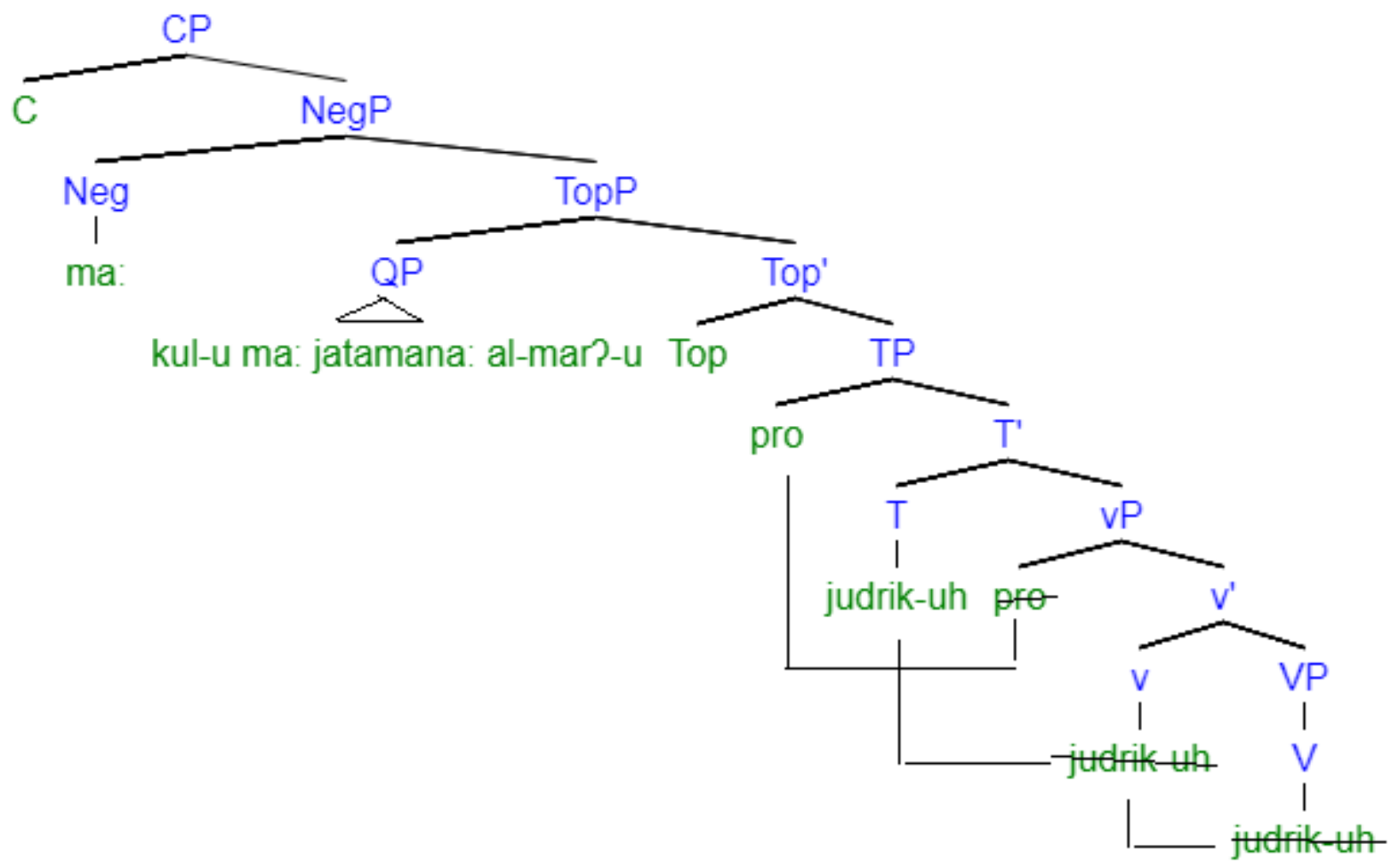

The QP kul-u ma: jatamana: al-mar?-u is a topicalized QP in Spec TopP. The verb judrik-uh is the head $\mathrm{v}$ of the vP. The subject of this verb is small pro, the finite null subject. This pro is bound by the antecedent al-mar?- $u$ which is the thematic subject of the embedded clause kul ma: jatamana: al-mar?-u in accordance with pro theory (Chomsky 1981). This pro carries agreement features with its DP antecedent al-mar?- $u$. These agreement features are the same person, number and gender. Thus, this pro is $3^{\text {rd }}$ person, masculine, plural, finite null subject.

The internal structure of the QP in $32 \mathrm{a}$ is as follows: 


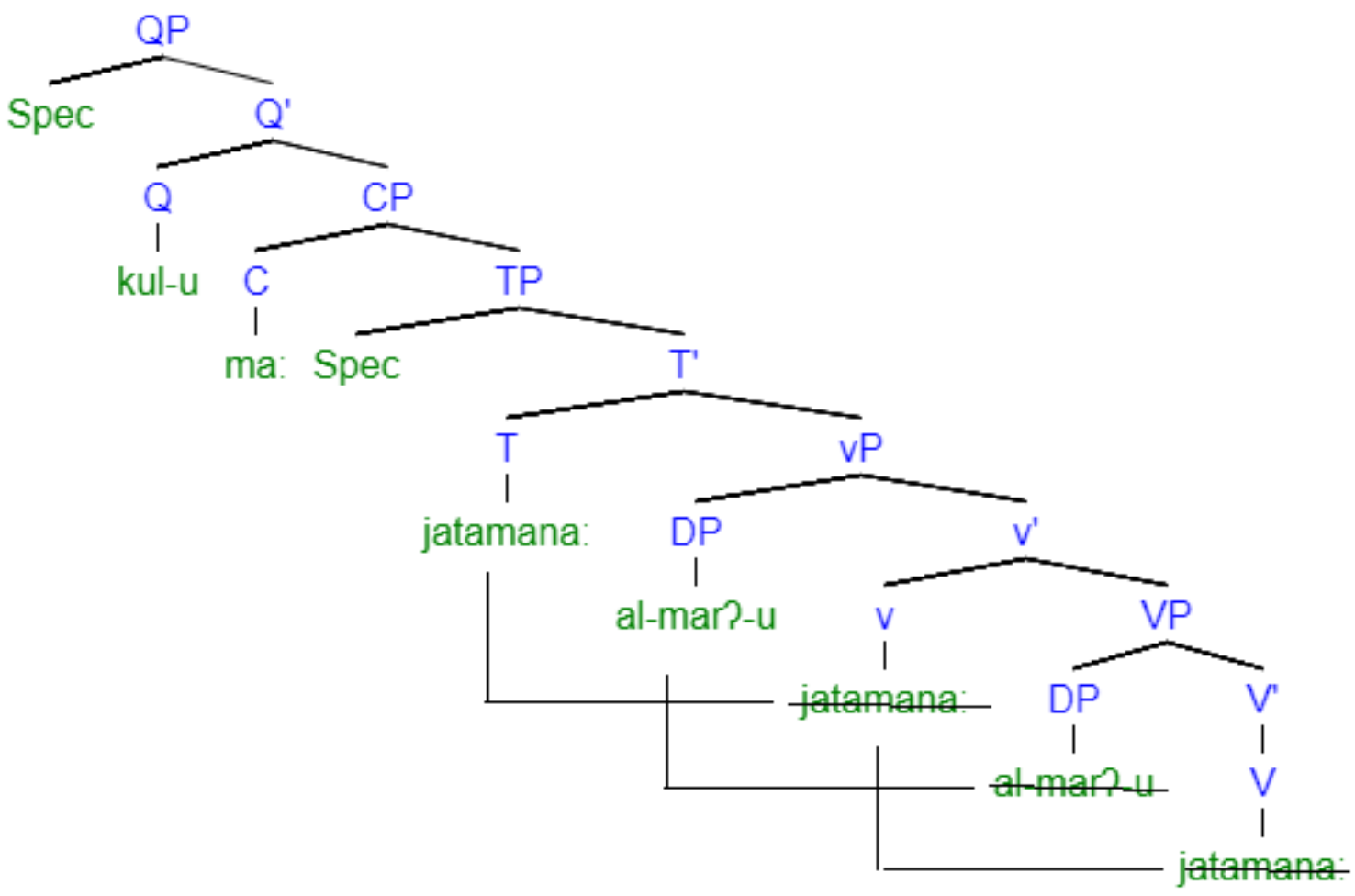

In the following examples, the embedded clause is an object of the verb and the quantifier $k u l$ is assigned accusative case by it:

34) ma: judrik al-mar?-u kul-a ma: jatamana:

Not realize the-man-nom all-acc that wish

"Man cannot realize all that he wishes for"

35) ma: jadGu: kul-u ra?i al-fata: ila: rufd-in

Not guide all-nom reason the-boy to wisdom-gen

"Not all the opinions of the boy are wise"

In the examples 32 through 35, the universal quantifier has the meaning of 'some' since it is c-commanded by the negative operator. According to alJurjani (2001, p.187), kul is in the scope of negation $(\neg \forall)$. Thus it has the meaning of "some". The resulting meaning is: "Man realizes some of what he wishes" for examples 32 and 34, and "Some of the boy's opinions are wise" for 33 and 35.

The negative $m a$ : is immediately adjacent to the verb and negates it. The predicate judrik has the external argument the DP al mar?-u and the internal argument the clausal object the QP kul ma: jatamana: Within its thematic 
domain, the $\mathrm{vP}$ has the head $\mathrm{v}$ judrik and its sister complement the QP kul ma: jatamana: The Spec vP is occupied by the DP al-mar?- $u$. The negative operator occupies the head Neg position of $\mathrm{NegP}$ and it has scope over the rest of the structure. The structure can be shown below:

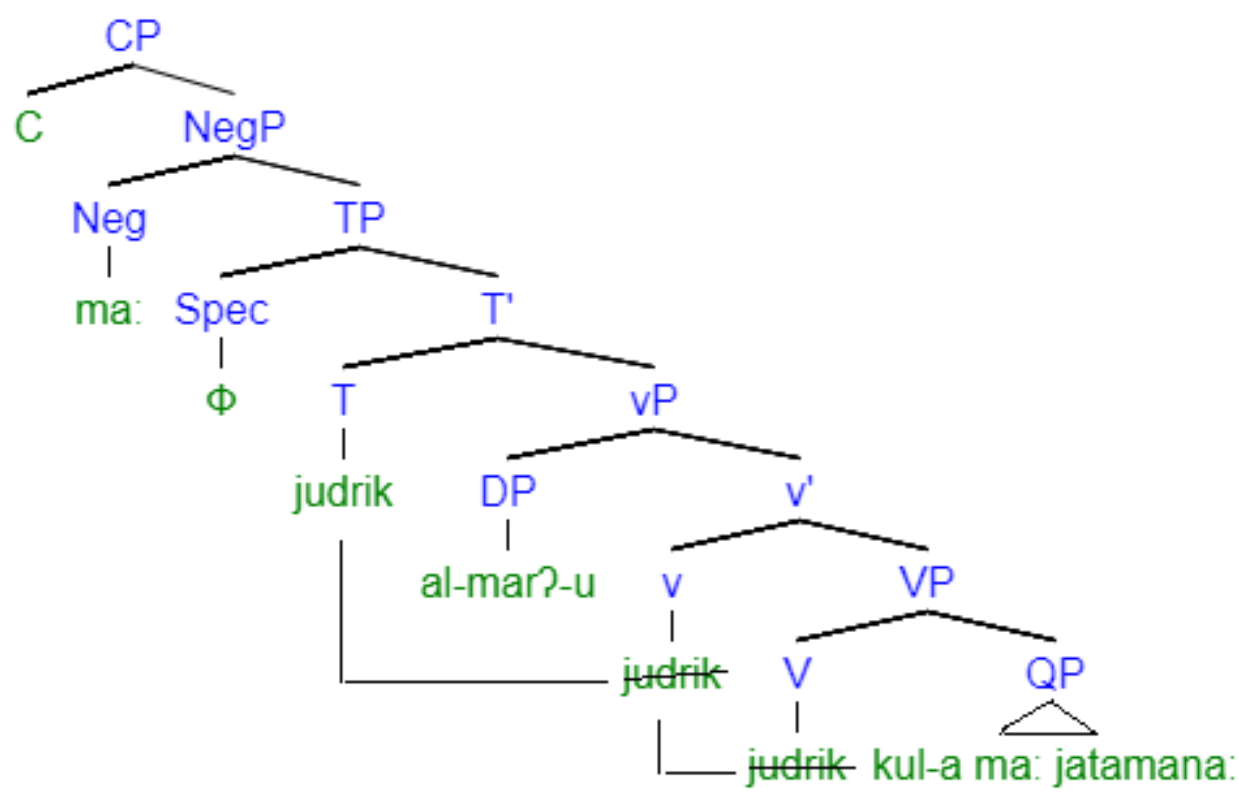

Semantically, it has the meaning: man realizes some of that he wishes for. The negation particle c-commands the whole structure. Its meaning is: For all what man wishes for is such that man realizes some of it $(\neg \forall)$. The following are more examples presented by al-Jurjani $(2001$, p.187) to demonstrate the scope of the logical operator kul. They show that when it is moved to the front, it has wide scope:

36) kul-u ma: jatamana: al-mar?-u la: judrik-uh All-nom that wishes the -man-nom not realize-resumptive pronoun

"man cannot realize all that he wishes"

37) kul-u ra?i al-fata: la: jadS-u: ila: rufd-in

All-nom opinions the-boy not guides to wisdom-gen

"The opinions of the boy are not wise"

Al-Jurjani (2001, p.187) postulates that "when kul "all" is in the scope of the negation by following the negative particle, the meaning will be negating the 
inclusiveness (of the quantifier $\mathrm{kul}$ ) and not negating the verb (the action) itself. When kul is outside the scope of negation, the meaning rendered will be negating the verb or the action (altogether)".

He justifies this by assuming that when a structure starts with the quantifier $\mathrm{kul}$, the negation is under the wide scope of it. In other words, meaning of inclusive quantification has a scope on the negation meaning. Thus the quantifier $k u l$ here has wide scope and the Neg operator la: has narrow scope.

In 36, the QP kul-u ma: jatamana: al-mar?-u is topicalized and occupies Spec TopP and the resumptive pronoun attached to the verb judrik is coreferential with the topicalized element. The NegP is positioned under the TopP and is headed by the Neg la: Under the NegP is the TP below which is the $\mathrm{vP}$ headed by the $\mathrm{v}$ judrik-uh and the Spec $\mathrm{vP}$ position is occupied by the finite null subject pro which agrees with its antecedent the DP al-mar?- $u$ in its phi features. The derivation can be shown below:

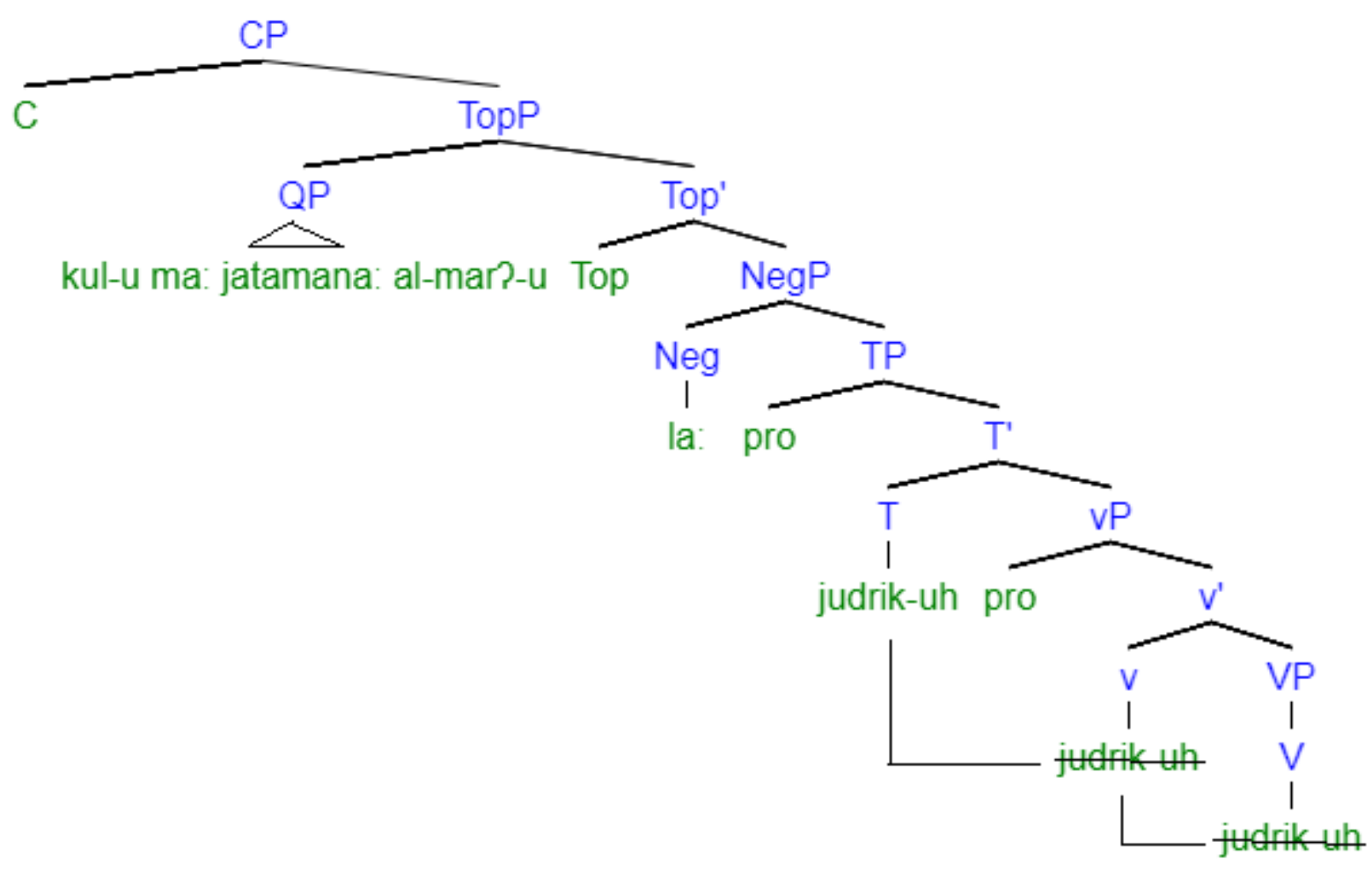

The quantifier $k u l$ has wide scope on negation $(\forall \neg)$, yielding the meaning: "None of what man wishes is such that he realizes". 


\section{Conclusion:}

In conclusion, the fundamental goal of this paper is to account for the change of meaning that results from narrow and wide scope interaction. Two different readings can be obtained based on two different logical structures and are prompted by the quantifier movement. In order to account for these two readings, the research made use of logical structure, and the notions of Movement, Scope and C-Command which are closely related. The generalization reached is that the universal quantifier $k u l$ "all" in CA has a partial reading, i.e. narrow scope when it falls within the scope of the negative operator. On the other hand, when topicalized, it has wide scope or the upper hand over the negative operator. It is demonstrated that the scope relation in CA is determined at surface structure, rather than at LF. The whole analysis sheds light on al-Jurjani's contribution to the syntax-semantics interface. This becomes evident by his explanation of the semantic effect of the syntactic movement of the logical operators under discussion. 


\section{References}

Abney, S. (1987). The English noun phrase in its sentential aspect. Ph.D. dissertation. MIT: Cambridge.

Al-Jurjani, A.-Q. (2001). Dala'il Al-I'jaaz (A. Hindawi (Ed.)). Dar al-kutub alilmiya: Beirut.

Al-Zajjaji, A. (1984). Al-Jumal fi al-Nahw (A. T. Al-Hamad (Ed.)). Musasat alRisala. Dar al-Amal: Irbid.

Amer, W. (2003). On floating quantifiers in English and Arabic. Journal of the Islamic University of Gaza. Vol.11 (2) pp.1-24

Benmamoun, E. (1992). Functional and Inflectional Morphology: Problems of Projection, Representation, and Derivation. PhD. dissertation. University of Southern California.

Benmamoun, E. (1999). The syntax of quantifiers and quantifier float. Linguistic Inquiry. Vol.30. (4)621-642.

Benmamoun, E. (2000). The feature structure of functional categories: A comparative study of Arabic dialects. Oxford University Press.

Benmamoun, A. (2008). Negation in Standard Arabic. In Essays in honor of Jean Roger. MIT.

Bernardi, R. (2002). Reasoning with polarity in categorial type logic. Ph.D dissertation. University of Utrecht.

Cheng, L. (1997). On the typology of wh- questions. Garland Publishing: New York.

Chomsky, N. (1955). Logical structure of linguistic theory (a typescript of Chomsky in preparation for his Ph.D. Thesis).

Chomsky, N. (1957). Syntactic structures. De Gruyter: Berlin.

Chomsky, N. (1965). Aspects of the theory of syntax. MIT Press. 
Chomsky, N. (1977). On wh-movement. In P. Culicover, T. Wasow \& A. Akmajian (Eds.) Formal Syntax, 71-132. Academic Press: New York.

Chomsky, N \& Lasnik, H. (1977). Filters and control. Linguistic Inquiry (8)425504.

Chomsky, N. (1980). On binding. Linguistic Inquiry, (11)1-46.

Chomsky, N. (1981). Lectures on Government and Binding. Foris: Dordrecht.

Chomsky, N. (1986) Barriers, MIT Press, Cambridge Mass.

Chomsky, N. (1993). A minimalist program for linguistic theory. In K. Hale and S. J. Keyser (Eds.), The view from building 20. Cambridge, Mass.: MIT Press, 1-52.

Chomsky, N. \& Lasnik, H. (1993). Principles and parameters in syntax: An international handbook of contemporary research. De Gruyter. Berlin.

Chomsky, N. (1995). The minimalist program. MIT Press.

Dayal, V. (2012). The syntax of scope and quantification. In M. Den-Dikken (Ed.), The Cambridge handbook of Generative Syntax. Cambridge University Press.

Doron, E. (1986). The pronominal copula as agreement clitic. In H. Borer (Ed.) Syntax and semantics. Vol.19 pp.313-332

Fakih, A. H. (2006). Licensing movement and feature checking in Standard Arabic: A minimalist approach. Journal of King Saud University, 19(2), 37-54.

Gad, R. F. (2011). A syntactic study of wh-movement in Egyptian Arabic within the minimalist program. Ph.D dissertation. University of Leeds.

Horvath, J. (2005). Separating focus movement from focus. Tel-Aviv University. $\quad$ Retrieved from https://www.ling.upenn.edu/ kroch/courses/1x650/650-07/horvath05.pdf.

Hornstein, N. (1995). Logical form: From GB to minimalism. Blackwell: Oxford. 
Huang, C. T. (1994). "Logical Form" Chapter 3. In G. Webelhuth (Ed.), Government and binding theory and the minimalist program (pp. 127-175). Blackwell: Oxford.

Jelinek, E. (2002). Agreement, clitic, and focus in Egyptian Arabic. In J. Ouhalla and U. Shlonsky (Eds.), Themes in Arabic and Hebrew syntax (pp.71-105). Dordrecht: Kluwer.

Jenks, P. (2013). Quantifier raising: A historical precis. Meaning Sciences Club. http://linguistics.berkeley.edu/ jenks/Research_files/QuantifierRaising_Feb 2013.pdf.

Khalil, R. (2012). Al-Jurjani's ta'alluq vs. Chomsky's x-bar theory: A minimalist comparative approach. Ph.D. dissertation. Ain Shams University: Cairo.

Koopman, H \& Sportiche, D. (1988). Subjects. University of California: Los Angeles.

Koopman, H \& Sportiche, D. (1991). The position of subjects. Lingua, (85)211-258. North Holland.

Kuroda, S. Y. (1988). Whether we agree or not: A comparative syntax of English and Japanese. Linguisticae Investigationes (12) 1-47.

Ladefoged, P. \& Maddieson, I. (1996). The sounds of the world's languages. Blackwell Publishers: Oxford.

Larson, R. (1988). On the double object construction. Linguistic Inquiry (19)335-391.

Lakoff, G. \& Johnson, M. (1980). Metaphors we live by. University of Chicago Press.

May, R. (1977). The grammar of quantification. MIT Press.

May, R. (1985). Logical form: Its structure and derivation. MIT Press.

Mohammad, M. A. (2000). Word Order, agreement, and pronominalization in Standard and Palestinian Arabic. Benjamins. 
Ouhalla, J. (1993). Negation, focus and tense: The Arabic maa and laa. Rivista Di Linguistica, (5) 275-300.

Owens, J. (2013). The Oxford handbook of Arabic linguistics. Oxford University Press.

Reinhart, T. (1976). The syntactic domain of anaphora. Ph.D. dissertation. MIT: Cambridge

Rizzi, L. (1997). The fine Structure of the Left Periphery. In Liliane Haegeman, (Ed.) Elements of grammar: Handbook of generative syntax. Dordrecht: Kluwer.

Ruys, E. G. (2002). Wide scope indefinites. Utrecht University. Retrieved from https://semanticsarchive.net/Archive/TcyNzcwY/indefinites.pdf

Shlonsky, U. (1991). Quantifiers as functional heads: A study of quantifier float in Hebrew. Lingua (86)159-180.

Shlonsky, U. (1997). Clause structure and word order in Hebrew and Arabic: An essay in comparative Semitic syntax. Oxford University Press.

Shlonsky, U. (2002). Constituent questions in Palestinian Arabic. In J. Ouhalla and U. Shlonsky (Ed.), Themes in Arabic and Hebrew syntax (pp. 137160). Dordrecht: Kluwer.

Sibaweih, A. (1977). Al-kitab. (A. Haroun (Ed.)). Al-hay'a al-masriya al-a'ama 1-el kitab Cairo.

Soltan, U. (2007). On formal feature licensing in minimalism: Aspects of Standard Arabic morphosyntax. University of Maryland, College Park.

Soltan, U. (2011). On issues of Arabic syntax: An essay in syntactic argumentation. Brill's Annual of Afro-asiatic Languages and Linguistics (3) 236-280

Soltan, U. (2017). The fine structure of the Neg-domain: Evidence from Cairene Egyptian Arabic sentential negation. Retrieved from: https://www.semanticscholar.org/paper/The-Fine-Structure-of-the-Neg- 
Domain\%3A-Evidence-from-

$\underline{\text { Soltan/aed3f2b7e2fa275dc558ee21a5c11fb3b68213d1\#paper-header }}$

Sportiche, D. (1988). A theory of floating quantifiers and its corollaries for constituent structure. Linguiatic Inquiry (19) 452-449.

Travis, L. (1984). Parameters and effects of word order variation. Ph.D. dissertation. MIT.

Wahba, W. (1991). LF movement in Iraqi Arabic. In C. T. Huang and R. May (Eds.), Logical structure and linguistic structure (pp.253-276). Dordrecht: Kluwer.

Williams, E. S. (1975). Small clauses in English. In J. Kimball. (Ed.), Syntax and Semantics vol. 4. Academic Press: New York. 


\section{Appendix}

\section{Table 1: Arabic Consonants}

\begin{tabular}{|c|c|c|}
\hline $\begin{array}{l}\text { Arabic } \\
\text { Consonant }\end{array}$ & Description & Symbol \\
\hline أ & Voiced glottal stop & $?$ \\
\hline ب & Voiced bilabial stop & $\mathrm{b}$ \\
\hline$ت$ & Voiceless dento-alveolar stop & $\mathrm{t}$ \\
\hline$\dot{H}$ & Voiceless interdental fricative & $\theta$ \\
\hline ج & Voiced post-alveolar fricative & $d_{3}$ \\
\hline$\tau$ & Devoiced pharyngeal fricative & $\hbar$ \\
\hline$\dot{\tau}$ & Voiceless velar fricative & $\mathrm{x}$ \\
\hline د & Voiced dento-alveolar stop & $\mathrm{d}$ \\
\hline j & Voiced interdental fricative & ð \\
\hline J & Voiced alveo-palatal trill & $\mathrm{r}$ \\
\hline j & Voiced alveolar fricative & $\mathrm{z}$ \\
\hline 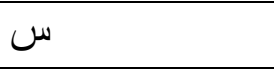 & Voiceless alveolar fricative & $\mathrm{s}$ \\
\hline ش & $\begin{array}{l}\text { Voiceless alveo-palatal } \\
\text { fricative }\end{array}$ & $\int$ \\
\hline ص & \begin{tabular}{|lll}
$\begin{array}{l}\text { Voiceless velarised alveolar } \\
\text { fricative }\end{array}$ & \\
\end{tabular} & $\mathrm{s}^{\varsigma}$ \\
\hline 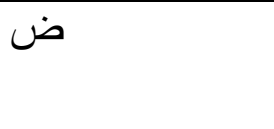 & $\begin{array}{l}\text { Voiced velarised dento- } \\
\text { alveolar stop }\end{array}$ & $d^{\varsigma}$ \\
\hline b & $\begin{array}{l}\text { Voiceless velarised dento- } \\
\text { alveolar stop }\end{array}$ & $\mathrm{t}^{\mathrm{s}}$ \\
\hline ظ & $\begin{array}{l}\text { Voiced velarised interdental } \\
\text { fricative }\end{array}$ & $\mathrm{z}$ \\
\hline$\varepsilon$ & Voiced pharyngeal fricative & G \\
\hline$\dot{\varepsilon}$ & Voiced uvular fricative & 8 \\
\hline ف & Voiceless labio-dental fricative & $\mathrm{f}$ \\
\hline ق & Voiceless uvular stop & $q$ \\
\hline ك & Voiceless velar stop & $\mathrm{k}$ \\
\hline J & Voiced alveolar lateral & 1 \\
\hline 5 & Voiced bilabial nasal & $\mathrm{m}$ \\
\hline ن & Voiced alveolar nasal & $\mathrm{n}$ \\
\hline o & Voiceless glottal fricative & $\mathrm{h}$ \\
\hline
\end{tabular}




\begin{tabular}{|l|l|l|}
\hline 9 & Voiced labiovelar glide & W \\
\hline $\mathfrak{S}$ & Voiced palatal glide & j \\
\hline
\end{tabular}

Table 2: Arabic Vowels

\begin{tabular}{|l|l|l|l|}
\hline Symbol & Description & Example & Meaning \\
\hline e & $\begin{array}{l}\text { Front short close } \\
\text { vowel muntaleq }\end{array}$ & Leaving \\
\hline a & $\begin{array}{l}\text { Front short open } \\
\text { vowel mubtada }\end{array}$ & Topic \\
\hline u & $\begin{array}{l}\text { Back short close } \\
\text { vowel Qulta }\end{array}$ & you said \\
\hline a: & $\begin{array}{l}\text { Front long open } \\
\text { vowel kita:b }\end{array}$ & Book \\
\hline u: & $\begin{array}{l}\text { Back long close } \\
\text { vowel axu:k }\end{array}$ & your brother \\
\hline i: & $\begin{array}{l}\text { High long close } \\
\text { vowel taqdi:m }\end{array}$ & Fronting \\
\hline Adapt & liged anadding & \\
\hline
\end{tabular}

Adapted from: Ladefoged and Maddieson (1996) 
المستخلص

يتمحور البحث الحالى حول مفاهيم الحركة والحيز الدلالى والتأثير النحوى والمستوى المنطقى - وهو

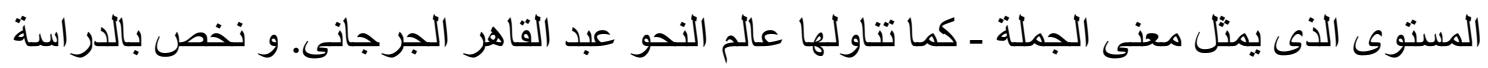
مصطلحي الجرجانى التأثير و الحيز واللذان يقابلهما مصطلحى التأثير النحوى والحيز الدلالى فى نظرية شومسكى النحو التوليدى. ان الهدف الرئيس من الدراسة هو بحث الحيز الدلالى للعو امل المنطقية

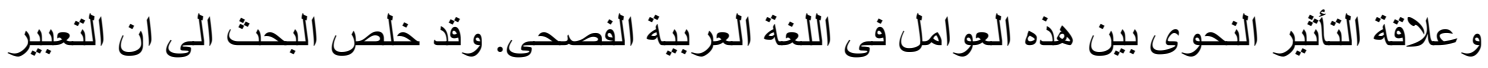

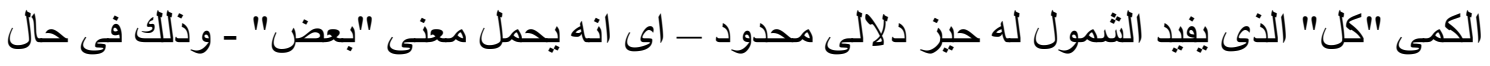

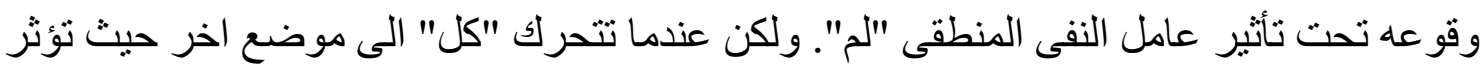

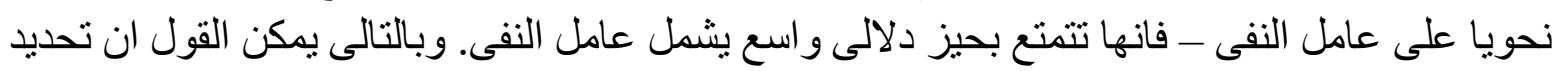
الحيز الدلالى يتم فى البنية السطحية للجملة وليس فى المستوى المنطقى الديلالى دلى.

الكلمات المفتاحية: الحيز الدلالى ـ التأثير النحوى ـ الحركة ـ المستوى المنطقى ـ اللغة العربية الفصحى

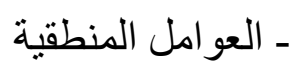

